\title{
Genetic diversity analysis in Plectranthus edulis (Vatke) Agnew populations collected from diverse geographic regions in Ethiopia using inter-simple sequence repeats (ISSRs) DNA marker system
}

\author{
Medhin Gebrehiwet ${ }^{1}$, Teklehaimanot Haileselassie ${ }^{2^{*}}$, Fekadu Gadissa ${ }^{3}$ and Kassahun Tesfaye ${ }^{2,4}$
}

\begin{abstract}
Background: Plectranthus edulis (Vatke) Agnew (Lamiaceae), locally known as Ethiopian potato syno. Ethiopian dinich, is one of the native Ethiopian edible tuber crops that has been significantly contributing to household food security for millions of subsistence farmers. However, its current production is declining to the extent of total extinction from several administrative regions where it used to be widely cultivated. It is one of the less researched crops regardless of being indigenous and its contribution to food security during time of scarcity. Therefore, we intended to assess the level of genetic diversity in 67 accessions, representing nine populations that were collected from diverse agro-ecologies in the country, using ISSR markers and hence, to generate a baseline information that assists marker assisted breeding, conservation and germplasm management efforts.

Results: In the present study, ten polymorphic ISSR markers were screened and optimized, that generated an average of 7.4 scorable bands per marker and revealed high overall percent polymorphism (95\%), Nei's gene diversity $(h=0.40)$ and Shannon index $(I=0.62)$ suggesting ISSR's effectiveness in detecting high levels of genetic diversity. A considerably high overall populations gene diversity (Nei's) $(h=0.32)$ and Shannon index $(I=0.47)$ were observed, revealing high potential of the populations for further breeding and conservation efforts particularly for population from Gurage administrative zone, which showed the highest values. Similarly, estimation of pairwise genetic distance revealed the importance of cross breeding population from Awi administrative zone to the rest populations. Analysis of hierarchical molecular variance (AMOVA) showed higher levels of genetic differentiation within populations (92\%), and collection regions (94\%) suggesting that either clonal mode of propagation in the crop or farmers selection pressure for important agronomic traits or both maintained the original heterozygosity in the crop. UPGMA phylogenetic analysis did not strictly group the populations based on their geographic region of origin, which could be attributed to the widely practiced tuber exchange and hence continuous human mediated exchange of genetic material and sharing of the same genetic base among the geographic regions.
\end{abstract}

Conclusions: The ISSR markers used in the present study were effective in revealing extent and patterns of genetic diversity in P. edulis populations. However, it is important to couple them with agro-morphological traits or codominant molecular markers to get more reliable information for use in breeding and conservation. Several of the potential administrative zones we covered are useful for P. edulis diversification and conservation. However, the crop is currently

\footnotetext{
*Correspondence: tekle1961@yahoo.com

${ }^{2}$ Institute of Biotechnology, Addis Ababa University, P. O. Box 1176, Addis

Ababa, Ethiopia

Full list of author information is available at the end of the article
} 
highly marginalized and this led to rapid decline in population size and loss of valuable agronomic traits. To address this challenge, there is an urgent need to take counteractive measures.

Keywords: Ethiopian potato, Genetic diversity, ISSR, Molecular marker, Plectranthus edulis

\section{Background}

Plectranthus edulis (Vatke) Agnew is locally known by several vernacular names among which, Ethiopian potato syno. Ethiopian dinich, is frequently used by the scientific community. It is an ancient tuber crop and native to Ethiopia. The crop belongs to family Lamiaceae, subfamily Nepetoideae, tribe Ocimeae, and genus Plectranthus $[1,2]$. It has a wide range of adaptations and used to be widely cultivated in the Central, Southern, Western, Northwestern and South-Western parts of Ethiopia. It is also reported to be found in warmer African countries such as Kenya, the Democratic Republic of Kongo, and Uganda, mainly in a wild form [3,4]. The crop is one of the four economically important tuber crops of the genus Plectranthus, such as P. esculentus (Livingstone potato), P. parviflorus (Sudan potato) and P. rotundifolius (Madagascar potato) [5-7].

In Ethiopia, P. edulis is primarily cultivated for food and as a source of income for millions of subsistence farmers, particularly in the country's densely populated highlands and semi-highlands. The crop is also widely used as a folk medicine and a source of nectar for honeybee $[8,9]$. However, production of the crop is currently declining to the extent of total extinction from several areas where it used to be widely cultivated. The decline in cultivation could be attributed to the current restricted distribution of the crop, low attention from the local scientific community, lack of awareness among younger farmers about the conservation and cultivation of the crop, research focus of the country that mainly targets cereals and commercial crops, poor shelf life of the crop, poor market opportunities, and introduction of exotic crops such as Irish potato to the area where it is cultivated [10]. Furthermore, the cultivation of the crop is currently restricted to elderly farmers mainly using marginal and degraded plots of land that are thought to be less important for other crops [11].

Genetic diversity, the total genetic variation in a species, could be assessed using a particular method or a combination of methods such as agro-morphological traits, biochemical and/or DNA marker(s) methods. Because of their ability to generate more reliable information, DNA molecular markers have been used for more than 30 years in estimating genetic diversity values [1214]. ISSR is one of the DNA based marker systems that involves the amplification of DNA segment oriented in opposite direction between two identical microsatellites repeat regions. It is widely applicable in genetic diversity study of crop plants and is therefore an important tool for characterizing and conserving germplasm, particularly in the breeding and management of endangered, rare and non-market-oriented endemic species $[15,16]$.

So far, very limited research activities have been conducted on P. edulis focusing only on agro-morphological diversity, ontogeny, micro-propagation, phytochemistry and nutritional analysis. As far as we know, very limited work is available using molecular DNA data such as EST-SSR [17] and no report is available on evaluation of its genetic diversity using ISSR markers. This study was therefore conducted in view of assessing the extent of genetic diversity within and among $P$. edulis populations collected from diverse agro-ecological regions in Ethiopia using ISSR markers. The generated information could be used as baseline in the future to support marker assisted breeding, conservation and germplasm management of this crop.

\section{Methods \\ Plant material}

Seeds of 67 P. edulis accessions, representing nine populations, were collected from the four main growing regions in the country (Table 1; Fig. 1). The seed samples for each accession were planted on separate pots filled with soil in a glasshouse at College of Natural Sciences, Addis Ababa University, Ethiopia. After planting, 5-week old young leave tissues were collected from five plants per accession and dried in a silica-gel filled zip-lockbag.

\section{Genomic DNA extraction, primer screening and optimization}

Genomic DNA extraction and PCR amplification were performed at the Plant Genetics Research Laboratory, College of Natural Sciences, Addis Ababa University, Ethiopia. Following the CTAB (2\% Cetyl Trimethyl Ammonium Bromide) protocol [18], approximately $0.5 \mathrm{~g}$ of silica gel dried and Restech mixer mill fine ground leaf powder was used for genomic DNA extraction with minor modifications such that the chloroform extraction step was repeated three times to yield high-quality DNA. The quality and quantity of DNA was checked using $1 \%$ w/v agarose gel and Thermo Scientific nanodrop spectrophotometer (NanoDrop 2000/2000c, Thermo Fisher Scientific, Wilmington, USA), respectively. 
Table 1 List of $P$. edulis populations and the administrative regions, zones and woredas of collection used in the present study, along with their altitude, latitude and longitude

\begin{tabular}{|c|c|c|c|c|c|c|c|}
\hline Population & Admin. Region & Admin. Zone & Admin. Woreda & Coll. Code & Altitude (m) & Latitude (dd) & Longitude (dd) \\
\hline \multirow[t]{7}{*}{ Awi } & Amhara & Awi & Banja & PE001 & 2554 & 10.937 & 36.912 \\
\hline & & & & PE002 & 2557 & 10.938 & 36.914 \\
\hline & & & & PE003 & 2643 & 10.973 & 36.948 \\
\hline & & & Fagta Lekoma & PE004 & 2555 & 11.058 & 36.893 \\
\hline & & & & PE005 & 2590 & 11.044 & 36.891 \\
\hline & & & Ankesha Goagsa & PE006 & 2380 & 10.873 & 36.896 \\
\hline & & & & PE007 & 2369 & 10.874 & 36.893 \\
\hline \multirow[t]{5}{*}{ Met } & Benshangul Gumuz & Metekel & Wenbera & PE008 & 2505 & 10.635 & 35.892 \\
\hline & & & & PE009 & 2427 & 10.623 & 35.346 \\
\hline & & & & PE010 & 2517 & 10.583 & 35.400 \\
\hline & & & & PE011 & 2483 & 10.614 & 35.646 \\
\hline & & & & PE012 & 2501 & 10.613 & 35.745 \\
\hline \multirow[t]{9}{*}{ CHL } & Central Highland, Oromia & Southwest Shewa & Darian & PE013 & 2599 & 8.694 & 37.896 \\
\hline & & & Goro & PE014 & 1828 & 8.412 & 37.872 \\
\hline & & & Woliso & PE015 & 1972 & 8.506 & 37.965 \\
\hline & & West Shewa & Cheliya & PE016 & 2924 & 9.109 & 37.399 \\
\hline & & & & PE017 & 2333 & 8.958 & 37.538 \\
\hline & & & & PE018 & 2469 & 8.973 & 38.007 \\
\hline & & & Dandi & PE019 & 2441 & 8.979 & 38.016 \\
\hline & & & & PE020 & 2446 & 8.981 & 38.020 \\
\hline & & & & PE021 & 2445 & 8.978 & 38.024 \\
\hline \multirow[t]{9}{*}{$I A B$} & Oromia & Ilu Aba Bora & Metu & PE022 & 1694 & 8.284 & 36.587 \\
\hline & & & & PE023 & 1714 & 8.285 & 36.585 \\
\hline & & & & PE024 & 1696 & 8.285 & 36.587 \\
\hline & & & Alle & PE025 & 1794 & 8.134 & 36.553 \\
\hline & & & Didessa & PE026 & 1915 & 8.485 & 36.642 \\
\hline & & & & PE027 & 1879 & 8.072 & 36.451 \\
\hline & & & & PE028 & 2096 & 8.135 & 36.452 \\
\hline & & & Bedele & PE029 & 1947 & 8.393 & 36.124 \\
\hline & & & & PE030 & 1901 & 8.483 & 36.370 \\
\hline \multirow[t]{9}{*}{$\mathrm{Jim}$} & & Jimma & Goma & PE031 & 1605 & 7.868 & 36.593 \\
\hline & & & & PE032 & 1621 & 7.874 & 36.599 \\
\hline & & & Seka Che & PE033 & 1806 & 7.605 & 36.690 \\
\hline & & & Dedo & PE034 & 2181 & 7.505 & 36.892 \\
\hline & & & & PE035 & 2228 & 7.502 & 36.890 \\
\hline & & & Jimma & PE036 & 1835 & 7.636 & 36.763 \\
\hline & & & Sokoru & PE037 & 1719 & 7.655 & 36.845 \\
\hline & & & & PE038 & 1987 & 7.911 & 37.435 \\
\hline & & & & PE039 & 1927 & 7.919 & 37.431 \\
\hline \multirow[t]{8}{*}{ Ewo } & & East Wollega & Gida Ayana & PE040 & 1991 & 9.887 & 36.613 \\
\hline & & & & PE041 & 2126 & 9.920 & 36.594 \\
\hline & & & & PE042 & 2087 & 9.895 & 36.628 \\
\hline & & & Limmu & PE043 & 2166 & 9.927 & 36.473 \\
\hline & & & & PE044 & 2149 & 9.846 & 36.459 \\
\hline & & & & PE045 & 2151 & 9.846 & 36.458 \\
\hline & & & Kiramu & PE046 & 2163 & 9.983 & 36.870 \\
\hline & & & & PE047 & 2141 & 9.990 & 36.870 \\
\hline
\end{tabular}


Table 1 (continued)

\begin{tabular}{|c|c|c|c|c|c|c|c|}
\hline Population & Admin. Region & Admin. Zone & Admin. Woreda & Coll. Code & Altitude (m) & Latitude (dd) & Longitude (dd) \\
\hline \multirow[t]{7}{*}{ GGo } & \multirow[t]{7}{*}{ SNNPS } & \multirow[t]{7}{*}{ Gamo Gofa } & \multirow[t]{3}{*}{ Chencha } & PE048 & 2678 & 6.261 & 37.582 \\
\hline & & & & PE049 & 2705 & 6.262 & 37.579 \\
\hline & & & & PE050 & 2696 & 6.246 & 37.564 \\
\hline & & & \multirow[t]{4}{*}{ Dita } & PE051 & 2625 & 6.302 & 37.496 \\
\hline & & & & PE052 & 2602 & 6.301 & 37.488 \\
\hline & & & & PE053 & 2623 & 6.299 & 37.485 \\
\hline & & & & PE054 & 2513 & 6.309 & 37.487 \\
\hline \multirow[t]{8}{*}{ Gur } & & \multirow[t]{8}{*}{ Gurage } & \multirow[t]{3}{*}{ Endegagn } & PE055 & 2261 & 7.844 & 37.837 \\
\hline & & & & PE056 & 2445 & 7.848 & 37.848 \\
\hline & & & & PE057 & 2382 & 7.857 & 37.856 \\
\hline & & & \multirow[t]{2}{*}{ Enemorna Ener } & PE058 & 2131 & 8.017 & 37.847 \\
\hline & & & & PE059 & 2155 & 8.011 & 37.849 \\
\hline & & & \multirow[t]{3}{*}{ Gumer } & PE060 & 2878 & 7.964 & 38.063 \\
\hline & & & & PE061 & 2929 & 7.961 & 38.067 \\
\hline & & & & PE062 & 2906 & 7.958 & 38.071 \\
\hline \multirow[t]{5}{*}{ Wso } & & \multirow[t]{5}{*}{ Wolaita Sodo } & \multirow[t]{2}{*}{ Damot Gale } & PE063 & 2012 & 6.961 & 37.842 \\
\hline & & & & PE064 & 2159 & 6.917 & 37.818 \\
\hline & & & \multirow[t]{2}{*}{ SodoZuriya } & PE065 & 2215 & 6.880 & 37.792 \\
\hline & & & & PE066 & 2188 & 6.901 & 37.821 \\
\hline & & & Damot Sore & PE067 & 2099 & 6.905 & 37.640 \\
\hline
\end{tabular}

PE: Plectranthus edulis; Col.: collection; Admin.: administrative; SNNPs: South Nations Nationalities and Peoples; Seka che: Seka Chekorsa; dd: decimal degree geographic coordinate system

Twenty-five ISSR primers (Source: Primer kit 900 (UBC 900) obtained from University of British Columbia, Vancouver, Canada) were used during the initial screening for variability and reproducibility. Ten (seven di-nucleotides-five of which were anchored, two tri-nucleotides and one penta-nucleotide) polymorphic primers capable of generating reproducible bands were selected and optimized for the study (Table 2).

\section{PCR amplification and gel electrophoresis}

PCR amplification was conducted in a final volume of $25 \mu \mathrm{l}$ reaction mixture per sample containing $\mathrm{ddH}_{2} \mathrm{O}$ $(15.2 \mu \mathrm{l}), \mathrm{MgCl}_{2}(25 \mathrm{mM})(3.0 \mu \mathrm{l})$, Taq buffer $(10 \times$ reaction buffer $\mathrm{S})(2.5 \mu \mathrm{l})$, dNTPs $(1.25 \mathrm{mM})(1.0 \mu \mathrm{l})$, primer

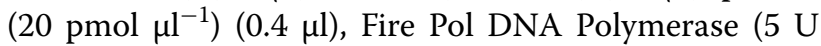
$\left.\mu^{-1}\right)(0.4 \mu \mathrm{l})$, (FIREPOL ${ }^{\circledR}$ DNA polymerase, Solis BioDyne, Estonia) and template DNA $\left(10 \mathrm{ng}^{-1} \mathrm{l}^{-1}\right)(2.5 \mu \mathrm{l})$. The amplification program was set at $94{ }^{\circ} \mathrm{C}$ for 4 min preheating and initial denaturation, followed by 40 cycles of denaturation at $94{ }^{\circ} \mathrm{C}$ for $15 \mathrm{~s}$, primer annealing at specific annealing temperature for each primer (Table 2) for $1 \mathrm{~min}$, extension at $72{ }^{\circ} \mathrm{C}$ for $1 \mathrm{~min}$ and $30 \mathrm{~s}$ each cycle and final extension at $72{ }^{\circ} \mathrm{C}$ for $7 \mathrm{~min}$. The PCR amplification products were electrophoresed using $1.67 \%$ $\mathrm{w} / \mathrm{v}$ agarose gel and size of the fragments was estimated against 100 bp DNA ladder (Thermo Fisher Scientific, Massachusetts, USA) (Fig. 2).

\section{Band scoring and data analysis}

The resulting bands were considered as unit character and scored as present (1), absent (0) and ambiguous (?). After successful scoring, the data were assembled into a binary data matrix with the samples in a row and the ISSR markers (loci) in column.

The resulting data matrix was analyzed using appropriate software. POPGENE ver. 1.32 [19] was used in particular to determine the percentage of polymorphic loci (PPL), gene diversity (h), and Shannon's information index (I). Arlequin ver. 3.01 [20] was used to determine the analysis of molecular variance (AMOVA) within and among the populations. Using NTSYS-pc version 2.02 [21] and Free Tree 0.9.1.50 [22], Jaccard's similarity coefficient-based unweighted pair group method with arithmetic average (UPGMA) [23] and neighborjoining $(\mathrm{NJ})[24,25]$ clusters were drawn to determine the genetic relationship between individual samples and populations considered in this study. To further examine the patterns of variation among individual samples, 


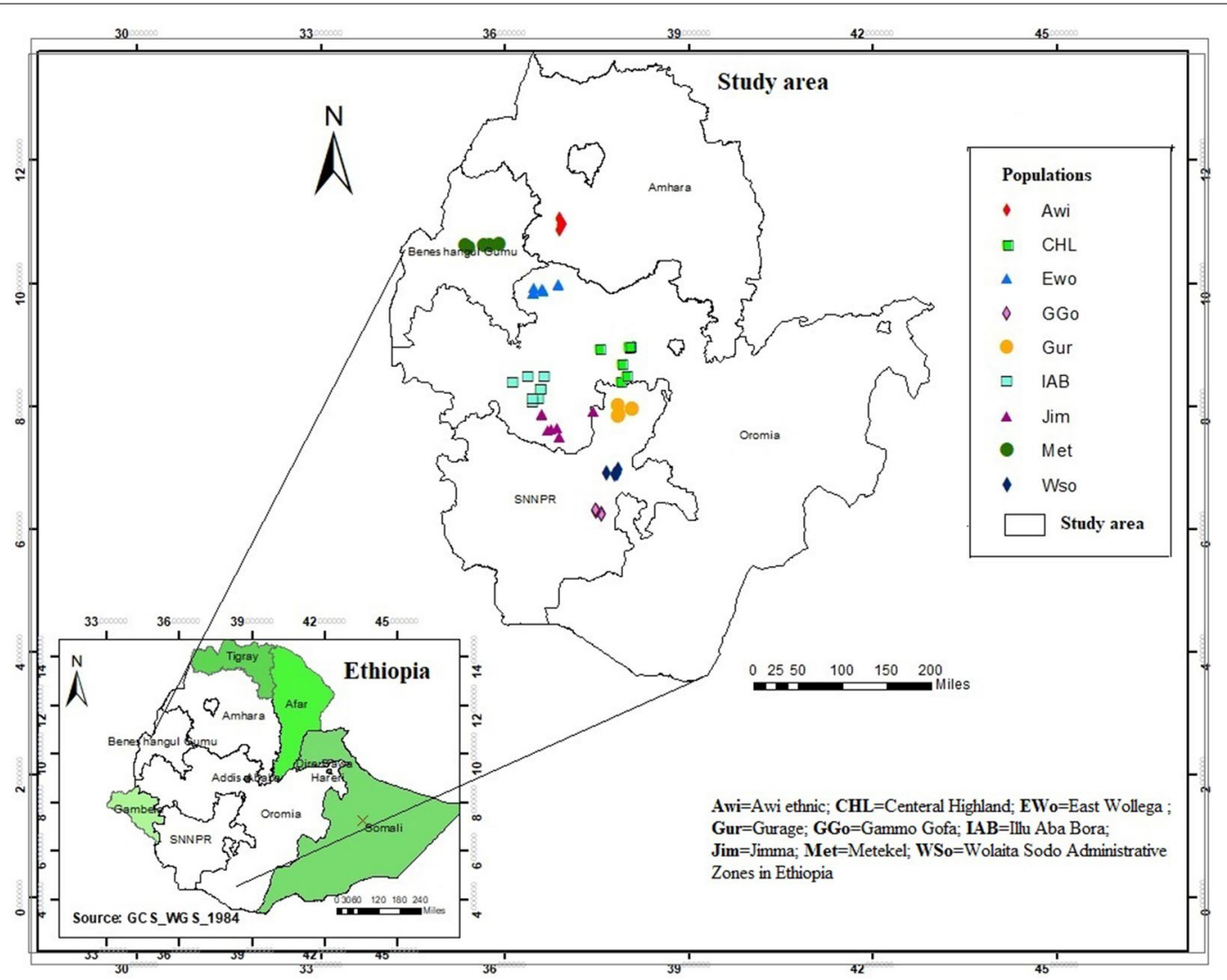

Fig. 1 A map of Ethiopia with federal administrative regions (left down) showing P. edulis accessions collection administrative regions (left up). The map was constructed based on geographic coordinates and elevation data gathered from each collection sites using global positioning system (GPS)

a principal coordinate analysis (PCoA) was performed using GenAlEx 6.5 [26].

\section{Results}

\section{ISSR primers and their banding patterns}

The ten screened and optimized ISSR primers produced 74 clear and scorable bands over the entire nine populations (an average of 7.4 per primer). The molecular weight of the fragments ranged between 200 and $2000 \mathrm{bp}$. UBC834 produced the highest number of scorable bands (12), whereas UBC-835 and UBC-868 scored the lowest (5 bands each) (Table 3$)$.

\section{Evaluation of the ISSR primers and their diversity indices}

The screened primers revealed that at least $91 \%$ of the loci were polymorphic throughout the entire population. Eight of the ten initially tested ISSR primers showed 100\% polymorphism across the entire population, while UBC866 showed the least percentage (71\%) of polymorphic loci. The highest gene diversity $(\mathrm{h}=0.48)$ and Shannon's information index $(I=0.68)$ were recorded for UBC-812, followed by UBC-834, 844 and 854 . UBC-835 showed the least gene diversity $(h=0.39)$ and UBC-866 showed the lowest Shannon's information index $(\mathrm{I}=0.58)$. Overall, there were 0.40 and 0.62 , respectively, gene diversity and Shannon's information index over the entire population (Table 3).

Among the nine populations studied, the population from Gurage administrative zone revealed the highest polymorphism $(\mathrm{PPL}=96.08 \%)$, gene diversity $(\mathrm{h}=0.44)$ and Shannon's information index $(\mathrm{I}=0.62)$, followed by population from Central Highland $(\mathrm{PPL}=84.31 \%$, $\mathrm{h}=0.36$ and $\mathrm{I}=0.51$ ). Populations from Metekel and Wolaita Sodo administrative zones showed the lowest values for PPL, $h$ and I (Table 4).

\section{Population genetic differentiation and distance}

Hierarchical AMOVA in both without prior grouping and grouping the populations according to their collection regions revealed a significantly higher $(p=0.001)$ percentage of differentiation ( $92 \%$ and $96 \%$, respectively) due to variance within populations and regions than differentiation among populations and regions $(8 \%$ and $4 \%$, 
Table 2 List of ISSR primers along with their annealing temperature, respective sequences and amplification efficiency used during optimization

\begin{tabular}{|c|c|c|c|c|}
\hline S/N & Primer & $\begin{array}{l}\text { Annealing } \\
\text { temperature } \\
\left({ }^{\circ} \mathrm{C}\right)\end{array}$ & Primer sequences & $\begin{array}{l}\text { Amplification } \\
\text { efficiency }\end{array}$ \\
\hline 1 & UBC-812 & $47^{\circ} \mathrm{C}$ & $(G A) 8 A$ & Excellent \\
\hline 2 & UBC-817 & $48^{\circ} \mathrm{C}$ & $(C A) 8 A$ & Poor \\
\hline 3 & UBC-818 & $47^{\circ} \mathrm{C}$ & $(\mathrm{CA}) 8 \mathrm{G}$ & No band \\
\hline 4 & UBC-826 & $47^{\circ} \mathrm{C}$ & $(\mathrm{AC}) 8 \mathrm{C}$ & No band \\
\hline 5 & UBC-834 & $47^{\circ} \mathrm{C}$ & $(C A) 8 A G$ & Excellent \\
\hline 6 & UBC-835 & $48^{\circ} \mathrm{C}$ & $(A G) 8 Y C$ & Very good \\
\hline 7 & UBC-839 & $49^{\circ} \mathrm{C}$ & $(\mathrm{TA}) 8 \mathrm{RG}$ & Poor \\
\hline 8 & UBC-841 & $48^{\circ} \mathrm{C}$ & $(G A) 8 Y C$ & Excellent \\
\hline 9 & UBC-844 & $48^{\circ} \mathrm{C}$ & $(\mathrm{AG}) 8 \mathrm{YT}$ & Excellent \\
\hline 10 & UBC-848 & $48^{\circ} \mathrm{C}$ & $(\mathrm{CA}) 8 \mathrm{RG}$ & No band \\
\hline 11 & UBC-851 & $49^{\circ} \mathrm{C}$ & $(\mathrm{GT}) 8 \mathrm{YG}$ & Poor \\
\hline 12 & UBC-852 & $48^{\circ} \mathrm{C}$ & $(\mathrm{AC}) 8 \mathrm{~T}$ & Poor \\
\hline 13 & UBC-854 & $49^{\circ} \mathrm{C}$ & $(\mathrm{TC}) 8 \mathrm{RG}$ & Excellent \\
\hline 14 & UBC-857 & $49^{\circ} \mathrm{C}$ & $(\mathrm{AC}) 8 \mathrm{AYG}$ & Excellent \\
\hline 15 & UBC-860 & $52^{\circ} \mathrm{C}$ & $(\mathrm{TG}) 8 \mathrm{RA}$ & Poor \\
\hline 16 & UBC-864 & $48^{\circ} \mathrm{C}$ & (CA)8RT & Very poor \\
\hline 17 & UBC-865 & $47^{\circ} \mathrm{C}$ & $(\mathrm{CCG}) 6$ & Poor \\
\hline 18 & UBC-873 & $45^{\circ} \mathrm{C}$ & $(G A C A) 4$ & No band \\
\hline 19 & UBC-878 & $48^{\circ} \mathrm{C}$ & $(\mathrm{GGAT}) 4$ & Poor \\
\hline 20 & UBC-879 & $48^{\circ} \mathrm{C}$ & (CTTCA)3 & Poor \\
\hline 21 & UBC-866 & $55^{\circ} \mathrm{C}$ & $(\mathrm{CTC}) 6$ & Good \\
\hline 22 & UBC-868 & $55^{\circ} \mathrm{C}$ & $(\mathrm{GAA}) 6$ & Excellent \\
\hline 23 & UBC-880 & $48^{\circ} \mathrm{C}$ & $(G G A G A) 3$ & Excellent \\
\hline 24 & UBC-881 & $49^{\circ} \mathrm{C}$ & (GGTG)3 & No band \\
\hline 25 & UBC-888 & $47^{\circ} \mathrm{C}$ & $\mathrm{BDB}(\mathrm{CA}) 7$ & Poor \\
\hline
\end{tabular}

Source: Primer kit 900 (UBC 900); Single-letter abbreviations for mixed base positions: $R=(A, G) ; Y=(C, T)$ respectively) (Table 5). The lower percentage of differentiation among the populations and regions was supplemented by low $\mathrm{F}_{\text {st }}(0.08$ and 0.04 , respectively) value (Table 5) and a higher overall gene flow $\left(\mathrm{N}_{\mathrm{m}}=1.54\right)$ (Table 4).

The populations pairwise genetic distance (D) ranged from 0.11 to 0.39 . In this regard, in the magnitude order, individuals from the Awi administrative zone population were relatively distantly related to the populations of Wolaita Sodo, Metekel, and Illu Aba Bora administrative zones. Similarly, population from Jimma administrative zone was relatively distant from the populations of Wolaita Sodo and Metekel administrative zones. The lowest estimate of genetic distance was observed between individuals of the Central Highland and East Wollega administrative zone populations (Table 6).

\section{Population genetic relationships}

Analysis of UPGMA based on Jaccard's similarity coefficients grouped the 66 accessions into five main clusters in which several accessions (31) were grouped together under cluster I followed by cluster II (24). Clusters III and IV included three accession each, while cluster $\mathbf{V}$ contained five accessions (Fig. 3). Population level grouping, however, formed three main clusters in which populations from Jimma, Awi, Central Highland and East Wollega administrative zones were grouped together (C3) and populations from Gamo Gofa, Metekel, Gurage and Illu Aba Bora administrative zones were grouped together $(\boldsymbol{C 1})$. Population from Wolaita Sodo administrative zone appeared as a monophyletic group (C2) (Fig. 4). In both phylogenetic trees, we observed a weak tendency to group according to their geographical origin except some collections from Northwest Ethiopia (population from Awi administrative area) and Southwest Ethiopia
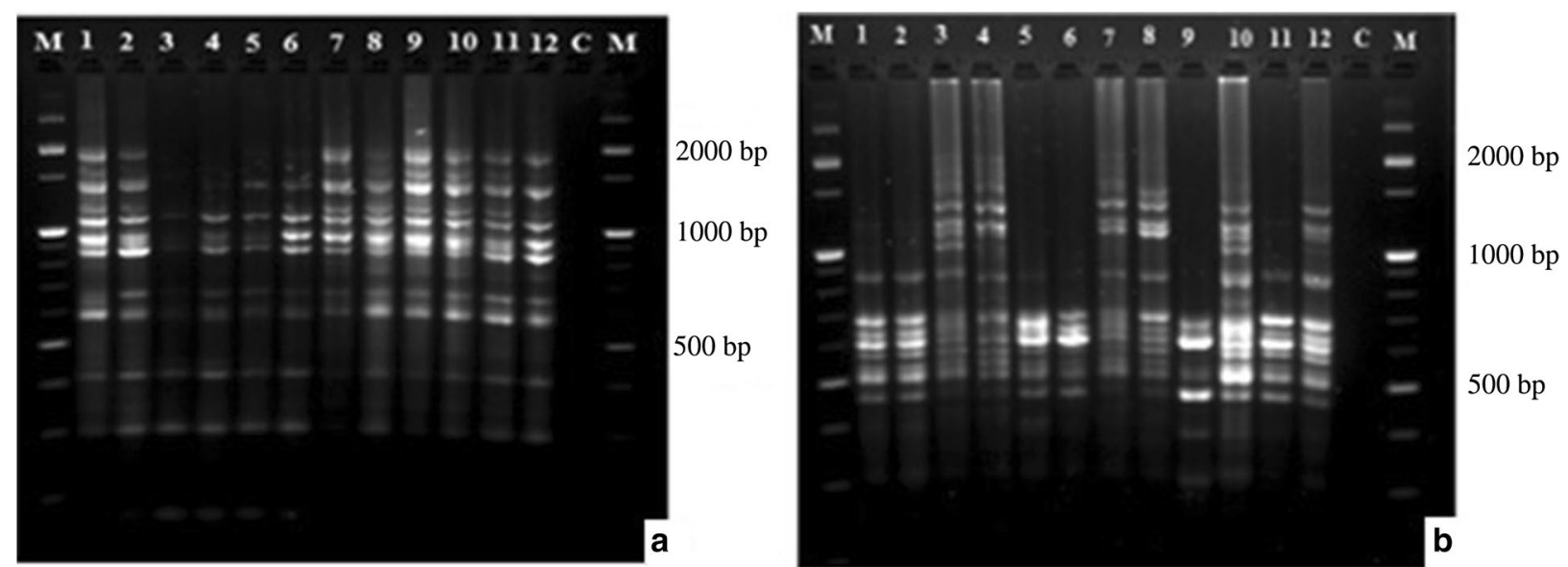

Fig. 2 ISSR profiles generated for 12 representative individual samples of P. edulis populations using UBC 324 (a) and UBC 812 (b). M=100 bp DNA ladder; $C=$ negative control; numbers from 1 to 12 represents PE001, PE004, PE008, PE013, PE016, PE022, PE025, PE034, PE042, PE050, PE056, and PE065 accessions, respectively 
Table 3 Number of reproducible scored bands (NRSB), number of polymorphic loci (NPL), percent of polymorphic loci (PPL), Nei's gene diversity (h), and Shannon's information index (I) scored over the entire nine populations studied

\begin{tabular}{llllll}
\hline Primers & NRSB & NPL & \multicolumn{1}{l}{ PPL } & \multicolumn{1}{l}{$\mathbf{h}$ SD } & I \pm SD \\
\hline UBC-812 & 9 & 9 & $100 \%$ & $0.48 \pm 0.02$ & $0.68 \pm 0.02$ \\
UBC-834 & 12 & 12 & $100 \%$ & $0.44 \pm 0.03$ & $0.63 \pm 0.05$ \\
UBC-835 & 5 & 4 & $80 \%$ & $0.39 \pm 0.01$ & $0.60 \pm 0.02$ \\
UBC-841 & 6 & 6 & $100 \%$ & $0.42 \pm 0.05$ & $0.61 \pm 0.03$ \\
UBC-844 & 7 & 7 & $100 \%$ & $0.44 \pm 0.04$ & $0.63 \pm 0.04$ \\
UBC-854 & 7 & 7 & $100 \%$ & $0.44 \pm 0.04$ & $0.63 \pm 0.04$ \\
UBC-857 & 9 & 9 & $100 \%$ & $0.41 \pm 0.09$ & $0.60 \pm 0.10$ \\
UBC-866 & 7 & 5 & $71 \%$ & $0.40 \pm 0.04$ & $0.58 \pm 0.04$ \\
UBC-868 & 5 & 5 & $100 \%$ & $0.41 \pm 0.03$ & $0.62 \pm 0.03$ \\
UBC-880 & 7 & 7 & $100 \%$ & $0.40 \pm 0.10$ & $0.59 \pm 0.12$ \\
Mean & 7.4 & 7.1 & $95 \%$ & $0.40 \pm 0.05$ & $0.62 \pm 0.05$ \\
\hline
\end{tabular}

(populations from Gurage and Jimma administrative areas) that formed their own mini-clusters (Fig. 3).

Analysis of principal components (PCoA) based on Nei's [27] genetic distance revealed $29.68 \%$ of the total variation for the first three $(12.77 \%, 9.52 \%, 7.39 \%$, respectively) principal axes. The $2 \mathrm{D}$ coordinates showed similar patterns of clustering with that of populations' UPGMA, except for a considerable number of accessions from the administrative zones of Awi, Jimma and Illu Aba Borathat tended to form their own distinct cluster (Fig. 5).

\section{Discussion}

Population genetic diversity and implications for selection and conservation

ISSR marker system is one of the widely used molecular markers for assessing the extent and patterns of genetic diversity and for deducing phylogenetic relationships in a variety of crop species. Similarly, it has been used in a

Table 4 Number of individuals per population (NIPP), Number of polymorphic loci (NPL), percent polymorphism (PP), Nei's gene diversity (h), and Shannon's information index (I) for the nine populations recorded over the entire ten loci studied

\begin{tabular}{lllllll}
\hline Pop & NIPP & NPL & PPL & $\mathbf{h} \pm$ SD & $\mathbf{I} \pm \mathbf{S D}$ & $\mathbf{G}_{\mathbf{s t}}^{\mathbf{a}}$ \\
\hline Awi & 7 & 61 & 82.35 & $0.33 \pm 0.19$ & $0.48 \pm 0.26$ \\
CHL & 9 & 62 & 83.78 & $0.36 \pm 0.18$ & $0.51 \pm 0.25$ & $\mathbf{N}_{\mathbf{m}}^{\mathbf{a}}$ \\
EWo & 8 & 59 & 79.73 & $0.33 \pm 0.19$ & $0.48 \pm 0.26$ \\
Gur & 8 & 71 & 95.94 & $0.44 \pm 0.11$ & $0.62 \pm 0.15$ & \\
GGo & 7 & 51 & 68.91 & $0.31 \pm 0.22$ & $0.44 \pm 0.30$ & \\
IAB & 9 & 52 & 70.27 & $0.30 \pm 0.21$ & $0.43 \pm 0.29$ & \\
Jim & 9 & 59 & 79.73 & $0.34 \pm 0.19$ & $0.49 \pm 0.26$ & \\
Met & 5 & 45 & 60.81 & $0.26 \pm 0.22$ & $0.38 \pm 0.32$ & \\
WSo & 5 & 44 & 59.5 & $0.26 \pm 0.23$ & $0.37 \pm 0.32$ & 0.24 \\
Mean & 7.4 & 56 & 75.66 & $0.32 \pm 0.19$ & $0.47 \pm 0.27$ & 1.54 \\
\hline
\end{tabular}

See Table 1 for the description

Pop populations

${ }^{\text {a }} \mathrm{N}_{\mathrm{m}}=$ estimate of gene flow from $\mathrm{G}_{\mathrm{st}}$ where $\mathrm{N}_{\mathrm{m}}=0.5\left(1-\mathrm{G}_{\mathrm{st}}\right) / \mathrm{G}_{\mathrm{st}}$

Table 5 Analysis of hierarchical molecular variance (AMOVA) without prior grouping and with grouping the populations into their collection regions

\begin{tabular}{|c|c|c|c|c|c|c|c|}
\hline & Sources of variation & df & Sum of squares & $\begin{array}{l}\text { Variance } \\
\text { components }\end{array}$ & $\begin{array}{l}\text { Percentage } \\
\text { of variation (\%) }\end{array}$ & Fixation index & $p$ value \\
\hline \multirow[t]{3}{*}{ Without grouping } & Among populations & 8 & 140.6 & $0.93 \mathrm{Va}$ & 8 & 0.08 & $<0.001$ \\
\hline & Within population & 58 & 616.4 & $10.81 \mathrm{Vb}$ & 92 & & \\
\hline & Total & 66 & 757.00 & 11.74 & 100 & & \\
\hline \multirow[t]{3}{*}{ With grouping } & Among regions & 3 & 53.73 & $0.48 \mathrm{Va}$ & 4 & 0.04 & $<0.001$ \\
\hline & Within regions & 62 & 703.27 & $11.34 \mathrm{Vb}$ & 96 & & \\
\hline & Total & 65 & 757.00 & 11.82 & 100 & & \\
\hline
\end{tabular}

$d f$ degrees of freedom 
Table 6 Nei's original measure of pairwise genetic distance for the nine $P$. edulis populations considered in the study (the italic values stand for the higher and lower pairwise genetic distances)

\begin{tabular}{|c|c|c|c|c|c|c|c|c|c|}
\hline Pop & Awi & CHL & EWo & Gur & GGo & $I A B$ & $\mathrm{Jim}$ & Met & WSo \\
\hline Awi & $* * * *$ & & & & & & & & \\
\hline $\mathrm{CHL}$ & 0.13 & $* * * * *$ & & & & & & & \\
\hline EWo & 0.11 & 0.09 & $* * * *$ & & & & & & \\
\hline Gur & 0.21 & 0.12 & 0.16 & $* * * *$ & & & & & \\
\hline GGo & 0.20 & 0.17 & 0.19 & 0.15 & $* * * *$ & & & & \\
\hline$I A B$ & 0.34 & 0.18 & 0.22 & 0.11 & 0.20 & $* * * *$ & & & \\
\hline $\mathrm{Jim}$ & 0.15 & 0.18 & 0.19 & 0.15 & 0.18 & 0.29 & $* * * *$ & & \\
\hline Met & 0.35 & 0.19 & 0.24 & 0.16 & 0.17 & 0.16 & 0.30 & $* * * *$ & \\
\hline WSo & 0.39 & 0.20 & 0.22 & 0.17 & 0.24 & 0.17 & 0.32 & 0.27 & $* * * *$ \\
\hline
\end{tabular}

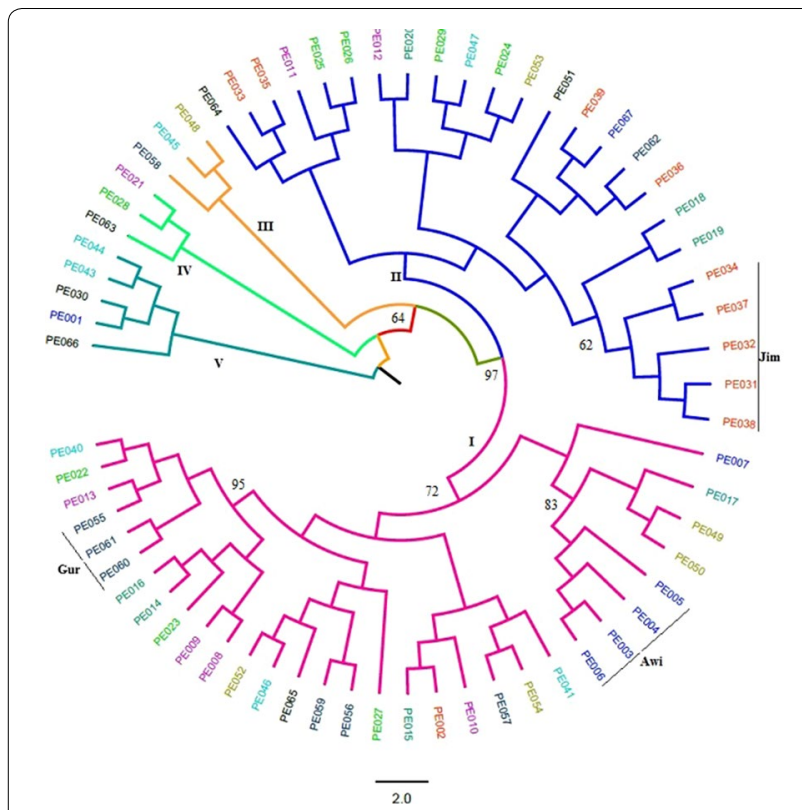

Fig. 3 UPGMA based cluster analysis of the 66 P. edulis accessions where, PE represents Plectranthus edulis and along with numbers ranging from 001-067 stands for the individual accessions. Corresponding populations are shown in Table 1. Numbers at the roots of the branches are bootstrap values, and bootstrap values of less than $60 \%$ were not shown wide variety of plants worldwide to study genetic variation $[12,28]$.

The ten reproducible ISSR markers selected and used in the present study showed an overall high level of polymorphism (95\%) which implies their great usefulness in revealing and evaluating the level of genetic diversity among and within $P$. edulis populations. There have been similar reports in other endemic root and tuber crops such as sweet potato [28], yam [29] and anchote

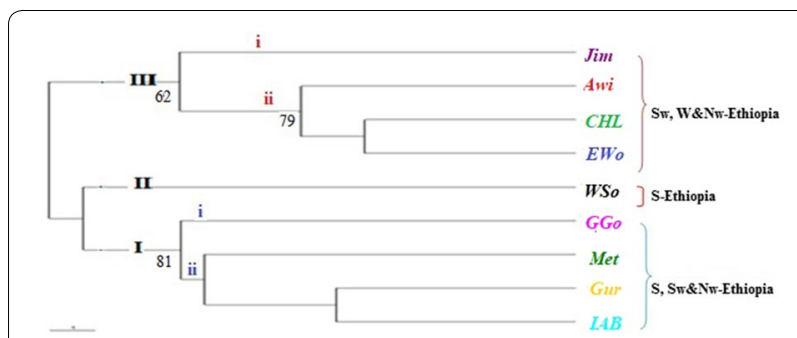

Fig. 4 UPGMA based dendrogram for the nine P. edulis populations used in the study. Numbers at the roots of the branches are bootstrap values, and bootstrap values of less than $60 \%$ were not shown

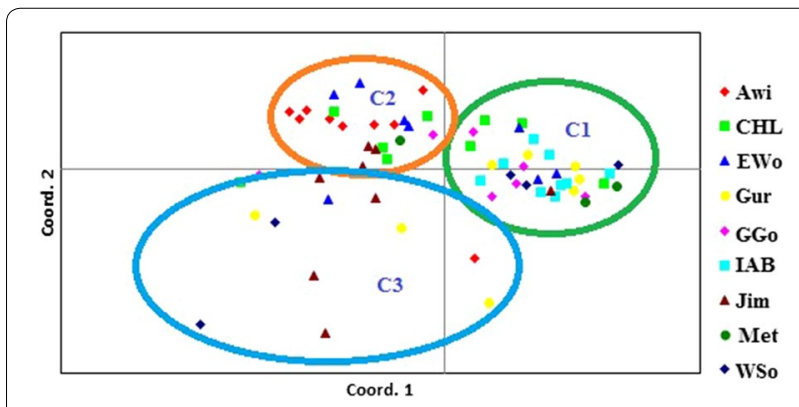

Fig. 5 Two-dimensional PCoA representations of genetic relationships among the 67 P. edulis accessions based on Jaccard's coefficients of similarity

[30] populations where ISSR markers showed high but varying levels of polymorphism. ISSR technique was also reported to be effective and successful in assessing genetic variability in other endemic and exotic species including lentil (Lens culinaris medikus) [31] and coffee (Coffee arabica L.) [32] from Ethiopia, Chinese grown pecan (American pecan) [33], and sesame [34].

The extent of genetic diversity in plant species is the result of one or more factors such as reproductive 
biology, life (evolutionary) history, geographic range of distribution, and various environmental factors that, in one way or another, affect mutation rates [35-37]. In this regard, the values in overall percent polymorphism, gene diversity and Shannon's information index observed in $P$. edulis populations could be attributed to the crop's clonal propagation nature in which only few parts of the population can preserve the original genetic diversity in the basal population. Furthermore, the efforts of local farmers, especially the elders, to maintain the original genetic diversity by preserving tubers over generations could be another reason for the observed higher genetic diversity indices, although the population size is rapidly declining from vast areas where it used to be widely cultivated. Twenty EST-SSR DNA markers detected a larger number of alleles and revealed a similar increasing trend in genetic diversity in twelve $P$. edulis populations that were collected from diverse agro-ecologies in the country [17].

High level of genetic variability is desirable because it increases fitness and thus reduces the likelihood of local extinction [38]. In this regard, P. edulis populations from Gurage, Central Highland, Awi, East Wollega and Jimma administrative zones, in order of magnitude, are important sources for improving the germplasm and taking immediate conservation actions.

On the other hand, the low values of percent polymorphism, gene diversity and Shannon's information index observed in populations from Metekel and Wolaita Sodo administrative zones could be attributed to the smaller sample size used from these specific areas. In addition, the recent introduction and domestication of the crop to some areas, especially, the Metekel zone, which is a bit pocketed and relatively recently dominated by the Oromo and Awi ethnic groups, could be also the probable reason. Compared to other ethnic groups in the area, these ethnic groups are known to be more familiar with P. edulis domestication and cultivation. In agreement with this, Rampersad et al. [39] suggested that there are higher levels of maintained gene diversity in larger and older populations compared to a newly colonized habitat. This is the result of an older population having sufficient timeframe to allow mutational events to introduce new genetic variants and to decrease the effects of genetic drift thus increasing the frequency of the alleles.

\section{Population genetic differentiation and distance}

Plectranthus edulis populations revealed a lower extent of genetic differentiation among the populations and the regions that could result from historical or contemporary exchange of germplasms, especially tubers for immediate planting, between or among zones and regions included in this study. The higher values of the overall gene flow $\left(\mathrm{N}_{\mathrm{m}}=1.54\right)$ and lower overall $\mathrm{G}_{\mathrm{st}}$ (equivalent to $\left.\mathrm{F}_{\mathrm{st}}\right)$ we observed could also support this premise as suggested by Wright [40] since the higher extent of gene flow $\left(\mathrm{N}_{\mathrm{m}}>1\right)$, and hence migration, is a powerful force for decreasing differentiation among populations [41].

On the other hand, the significantly higher genetic differentiation within populations and regions could be attributed to the clonal propagation nature of the crop, an important aspect in maintaining heterozygosity in the basal population over generations regardless of the current population size fluctuation. This can be explained by the fact that the crop is historically sexually reproduced through seeds, which is still rarely practiced at research sites, and this has allowed the crop to accumulate heterozygosity in the basal population to some extent. Tadele et al. [32] and Nascimento et al. [42] reported higher within population variation in clonally propagating endemic tuber crops such as anchote (Coccinia abyssinica) and yam, respectively. Similarly, Wodajo [43], and Seid et al. [44] reported higher levels of within population variation in safflower and Lepidium sativum, respectively.

The wide range of pairwise genetic distance that we detected (the highest being more than $4 \times$ of the lowest) generally indicates the high genetic variability in $P$. edulis populations that could be a valuable source for selection breeding. For this purpose, individuals from the Awi administrative zone versus Wolaita Sodo, Metekel, Illu Aba Bora and Gurage administrative zones, showing considerable pairwise genetic distance, could be used as parental sources. On the other hand, Mantel test revealed that the genetic distance did not correlate with geographic distance (data not shown) which again confirms intensive seed tuber exchange between or among farmers or the recent divergence of the crop from a common genetic base. Moulin et al. [45] reported lack of distancerelated genetic variability among sweet potato landraces because of widespread practice of exchanging accessions between neighboring farmers and relatives.

\section{Population genetic relationship}

The genetic relationships between and among P. edulis populations showed poor correlation between geographic origin and the patterns of clustering. Samples or populations from distant zones or regions have been found lumped together the same cluster and those from the same or nearby geographic areas have been placed under a different cluster and such grouping weakly supports the concept of "isolation by distance" [40]. Generally speaking, the clustering patterns once again denote the widely practiced tuber exchange and consequently, continuous gene flow and extensive sharing of genetic material among regions that led to reduced differentiation among the populations. However, results from other 
molecular marker systems such as short tandem repeats (STRs) is highly important in order to discriminate sufficiently and identify unique accessions before implementing the information for breeding and conservation.

\section{Conclusions}

From the present study, we conclude that ISSR marker system is useful in estimating the extent of genetic diversity and generating valuable information for use in further breeding and conservation measures in indigenous crops. However, in order to generate a more reliable information, it is important to combine it with other marker systems such as agro-morphological traits-based genetic diversity assessment or co-dominant molecular marker systems, such as SNPs, which have a higher potential for estimating population genetic structure.

On the basis of genetic diversity indices such as gene diversity, Shannon's information index, and percent of polymorphic loci, Gurage, Central Highland, Awi, East Wollega and Jimma administrative zones are relatively better areas for $P$. edulis diversification and conservation. The higher gene flow among the different regions, coupled with the current decline in population size, may result in loss of valuable agronomic traits unless counteracting action is taken.

Representative samples from all potential growing areas need to be collected exhaustively to provide a good estimate of the crop's existing genetic diversity for use in improving it and reversing its current rapid genetic erosion.

\section{Abbreviations \\ AMOVA: analysis of molecular variance; CTAB: cetyl trimethyl ammonium bromide; ISSR: inter-simple sequence repeats; SNNPs: Southern Nations, Nationalities, and Peoples' Region; PCoA: principal coordinates analysis; UPGMA: unweighted pair group with arithmetic mean.}

\section{Acknowledgements}

The authors would like to thank Addis Ababa University for financial, material and technical support to this research.

\section{Authors' contributions}

MG carried out DNA extraction and the laboratory work. MG, FG carried out sample collection, planting, leaf sample collection and data analysis. MG, $\mathrm{TH}, \mathrm{KT}$ and $\mathrm{FG}$ participated in experimental design, data interpretation and drafting the manuscript. All authors revised the draft the final manuscript. All authors read and approved the final manuscript.

\section{Funding}

The project was supported by Addis Ababa University, Thematic Research Project entitled 'Neglected indigenous root and tuber crops for Ethiopian future food security' (TRP-02).

\section{Availability of data and materials} Not applicable.

Ethics approval and consent to participate Not applicable.
Consent for publication

Not applicable.

\section{Competing interests}

The authors declare that they have no competing interests.

\begin{abstract}
Author details
${ }^{1}$ Department of Biotechnology, Aksum University, P.O. Box 1010, Aksum, Tigray, Ethiopia. ${ }^{2}$ Institute of Biotechnology, Addis Ababa University, P. O. Box 1176, Addis Ababa, Ethiopia. ${ }^{3}$ Biology Department, Madda Walabu University, P. O. Box 247, Bale Robe, Ethiopia. ${ }^{4}$ Ethiopian Institute of Biotechnology, Ministry of Science and Technology, P.O. Box 32853, Addis Ababa, Ethiopia.
\end{abstract}

Received: 2 April 2019 Accepted: 29 August 2019

Published online: 09 September 2019

\section{References}

1. Gurcharan SS. Plant systematics: an integrated approach. Enfield: Science Publishers; 2004.

2. GRIN (Germplasm Resource Information Network)[Online database]. National genetic resource program. National Germplasm Resource Laboratory, Beltssoille, Maryland USDA, ARS; 2005. http://www.ars-grin.gov2/ cgi-bin/npgs/html/taxon. Accessed 22 Oct 2017.

3. Garedew W, Tsegaye A, Tesfaye B, Hussein Mohammed H. Diversity analysis in Plectranthus edulis (Vatke) Agnew collection in Ethiopia. Inter J Biod Cos. 2013:5:561-6.

4. Westphal E. Agricultural systems in Ethiopia. Wageningen: Centre for Agricultural Publishing and Documentation; 1975.

5. Tindall HD. Vegetables in the tropics. London: Macmillan Press Ltd.; 1983. p. 734. https://doi.org/10.1007/978-1-349-17223-8.

6. Allemann J, Laurie SM, Thiarth S, Vorster HJ, Bornman CH. Sustainable production of root and tuber crops (potato, sweet potato, indigenous potato, cassava) in southern Africa. S Afri J Bot. 2004;70:60-6.

7. Jansen PCM. Plectranthus rotundifolius (Poiret) Sprengel. In: Flach M, Rumawas F, editors. Plant resources of South-East Asia, no 9. Plants yielding non-seed carbohydrates. Leiden: Backhuys publishers; 1996. p. 141-3.

8. Asfaw Z, Tadesse M. Prospects for sustainable use and development of wild food plants in Ethiopia. Econ Bot. 2001;55:47-62.

9. Reinhard F, Adi A. Honeybee Flora of Ethiopia. Adis Ababa: The National Herbarium; 1994.

10. Taye MA. Studies on agronomy and crop physiology of Plectranthus edulis (Vatke) Agnew. PhD thesis, Wageningen University, the Netherlands; 2008.

11. Mekbib Y, Deressa T. Exploration and collection of root and tuber crops in East Wollega and Ilu Ababora zones: rescuing declining genetic resources. Indian J Trad Know. 2016;15:86-92.

12. Reddy MP, Sarla N, Siddiq EA. Inter simple sequence repeat (ISSR) polymorphism and its application in plant breeding. Euphytica. 2002;128:9-17.

13. Semagn K, Bjørnstad A, Ndjiondjop M. An overview of molecular markers methods for plants. Afr J Biotechnol. 2006;5:2540-68.

14. Mishra Kundan K, Fougat RS, Ballani A, Thakur V, Jha Y, Bora M. Potential and application of molecular markers techniques for plant genome analysis. Int J Pure App Biosci. 2014;2:169-88.

15. Rao VR, Toby H. Genetic diversity and conservation and utilization of plant genetic resources. Plant Cell Tiss Org. 2002;68:1-19.

16. Song J. Genetic diversity and flowering in Clianthus and New Zealand sophora (Fabaceae). Ph.D. Dissertation. Massey University, Palmerston North, New Zealand; 2005.

17. Gadissa F, Tesfaye K, Dagne K, Geleta M. Genetic diversity and population structure analyses of Plectranthus edulis (Vatke) Agnew collections from diverse agro-ecologies in Ethiopia using newly developed EST-SSRS marker system. BMC Genet. 2018;19:92.

18. Borsch T, Hilu KW, Quandt D, Wilde V, Neinhuis C, Barthlott W. Noncoding plastid trnT-trnF sequences reveal a well resolved phylogeny of basal angiosperms. J Evol Biol. 2003;16:558-76.

19. Yeh FC, Boyle TJB. Population genetic analysis of co-dominant and dominant markers and quantitative traits. Belg J Bot. 1997;129:157-63. 
20. Excoffier L, Laval G, Schneider S. Arlequin (version 3.0): an integrated software package for population genetics data analysis. Evol Bioinform Online. 2007;1:47-50.

21. Rohlf FJ. Numerical taxonomy and multivariate analysis system, version 2.002. New York: Exeter software; 2000.

22. Pavlícek A, Hrdá S, Flegr J. Free-Tree-freeware program for construction of phylogenetic trees on the basis of distance data and bootstrap/jackknife analysis of the tree robustness: application in the RAPD analysis of genus Frenkelia. Folia Biol (Praha). 1999:45:97-9.

23. Sneath PHA, Sokal RR. Numerical taxonomy. San Francisco: WH Freeman and Company; 1973.

24. Saitou N, Nei M. The neighbour-joining method: a new method for reconstructing phylogenetic trees. Mol Biol Evol. 1987:4:406-25.

25. Studier JA, Keppler KJ. A note on the neighbor-joining method of Saitou and Nei. Mol Biol Evol. 1988;5:729-31.

26. Peakall PR, Smouse PE. GenAlEx 6.5: genetic analysis in Excel. Population genetic software for teaching and research —an update. Bioinformatics. 2012;28:2537-9.

27. Nei M. Genetic distance between populations. Am Nat. 1972;106:283-92.

28. Hu J, Nakatani M, Lalusin AG, Kuranouchi T, Fujimura T. Genetic diversity of sweet potato and wild relatives using inter simple sequence repeats (ISSR). Breeding Sci. 2003;53:297-304.

29. Zhou Y, Zhou C, Yao H, Liu Y, Tu R. Application of ISSR markers in detection of genetic variation among Chinese yam (Dioscorea opposite Thunb.) cultivars. Life Sci J. 2008;5:6-12.

30. Bekele A, Feyissa T, Tesfaye K. Genetic diversity of anchote (Coccinia abyssinica (Lam.) Cogn.) from Ethiopia as revealed by ISSR markers. Genet Resour Crop Evol. 2014;61:707-19.

31. Fikiru E, Tesfaye K, Bekele E. Genetic diversity and population structure of Ethiopian lentil (Lens culinaris Medikus) landraces as revealed by ISSR marker. Afr J Biotechnol. 2007:6:1460-8.

32. Tadele S, Mekbib F, Tesfaye K. Genetic diversity of coffee (Coffea arabica L.) landraces from Southern Ethiopia as revealed by inter simple sequence repeat marker. Glo Adv Res J Agric Sci. 2014;3:24-34.

33. Jia XD, Wang T, Zhai M, Li YR, Guo ZR. Genetic diversity and identification of Chinese-grown pecan using ISSR and SSR markers. Molecules. 2011;16:10078-92.

34. Alemu A. Genetic diversity of sesame (Sesamum indicum L.) from North Western Ethiopia using inter simple sequence repeat markers. Msc Thesis, Haramaya University, Haramaya, Ethiopia; 2011.
35. Loveless MD, Hamrick JL. Ecological determinants of genetic structure in plant population. Ann Rev Ecol Syst. 1984;15:65-95.

36. Hamrick JL, Godt MJ. Effects of life history traits on genetic diversity in plant species. Phil Trans R Soc Lond B. 1996. https://doi.org/10.1098/ rstb.1996.0112.

37. Milgroom MG. Recombination and the multilocus structure of fungal populations. Annu Rev Phytopathol. 1996;34:457-77.

38. Futuyma DJ. Sympatric speciation: norm or exception? In: Tilmon KJ, editor. Specialization, speciation, and radiation: the evolutionary biology of herbivorous insects. Berkeley: University of California Press; 2008. p. $136-48$.

39. Rampersad SN, Perez-Brito D, Torres-Calzada C, Tapia-Tussell R, Carrington CV. Genetic structure and demographic history of Colletotrichum gloeosporioides sensu lato and C. truncatum isolates from Trinidad and Mexico. BMC Evol Biol. 2013;13:130.

40. Wright S. Isolation by distance. Genetics. 1943;28:114-38.

41. Slatkin M. Gene flow and the geographic structure of natural populations. Science. 1987;236:787-92.

42. Nascimento WF, Rodrigues JF, Koehler S, Gepts P, Veasey EA. Spatially structured genetic diversity of the Amerindian yam (Dioscorea trifida L.) assessed by SSR and ISSR markers in Southern Brazil. Genet Resour Crop Evol. 2013. https://doi.org/10.1007/s10722-013-0008-y.

43. Wodajo B. Investigation of genetic diversity in Ethiopian collections of safflowers (Carthamus tinctorius) using ISSR markers. M.Sc. Thesis. Addis Ababa University, Addis Ababa, Ethiopia; 2012.

44. Seid M, Tesfaye K. Morphological and molecular characterization of Lepidium sativum population collected from Ethiopia. Afr J Plant Sci. 2015;9:215-22.

45. Moulin MM, Rodrigues R, Gonçalves LSA, Sudré CP, Pereira MG. A comparison of RAPD and ISSR markers reveal genetic diversity among sweet potato landraces (Ipomoea batatas (L.) Lam.). Acta Sci Agron. 2012;34:139-47.

\section{Publisher's Note}

Springer Nature remains neutral with regard to jurisdictional claims in published maps and institutional affiliations.
Ready to submit your research? Choose BMC and benefit from:

- fast, convenient online submission

- thorough peer review by experienced researchers in your field

- rapid publication on acceptance

- support for research data, including large and complex data types

- gold Open Access which fosters wider collaboration and increased citations

- maximum visibility for your research: over $100 \mathrm{M}$ website views per year

At $\mathrm{BMC}$, research is always in progress.

Learn more biomedcentral.com/submissions 